\title{
Article \\ Effect of Eucalyptus-Wood-Based Compost Application Rates on Avocado (Persea americana Mill) Foliar Nutrient Content and Fruit Yield
}

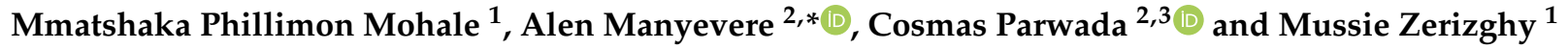 \\ 1 School of Agriculture and Environmental Science, Faculty of Science and Agriculture, University of Limpopo, \\ Polokwane 0699, South Africa; phillimon@malunganigroup.co.za (M.P.M.); mussie.zerizghy@ul.ac.za (M.Z.) \\ 2 Department of Agronomy, Faculty of Science and Agriculture, University of Fort Hare, \\ Alice 5700, South Africa; parwadac@zou.ac.zw \\ 3 Department of Agricultural Management, Faculty of Agricultural Sciences, Zimbabwe Open University, \\ Thomas Coulter Annex, Hwange 8306, Zimbabwe \\ * Correspondence: AManyevere@ufh.ac.za; Tel.: +27-79-098-0486
}

Citation: Mohale, M.P.; Manyevere, A.; Parwada, C.; Zerizghy, M. Effect of Eucalyptus-Wood-Based Compost Application Rates on Avocado (Persea americana Mill) Foliar Nutrient Content and Fruit Yield. Agronomy 2022, 12, 477. https://doi.org/ 10.3390/agronomy12020477

Academic Editors: Othmane Merah, Purushothaman Chirakkuzhyil Abhilash, Magdi T. Abdelhamid, Hailin Zhang, Bachar ZEBIB and Salvatore Camposeo

Received: 28 August 2021 Accepted: 28 September 2021 Published: 14 February 2022

Publisher's Note: MDPI stays neutral with regard to jurisdictional claims in published maps and institutional affiliations.

Copyright: (c) 2022 by the authors. Licensee MDPI, Basel, Switzerland. This article is an open access article distributed under the terms and conditions of the Creative Commons Attribution (CC BY) license (https:// creativecommons.org/licenses/by/ $4.0 /)$.

\begin{abstract}
Background: The effects of different fertilizer types and their application rates on leaf nutrient content and avocado yield are unclear. An evaluation of eucalyptus-wood-based compost applied at $0,5,10$, and $15 \mathrm{tha}^{-1}$ year $^{-1}$ on foliar nutrient content, yield, and fruit size distribution (\%) was completed at Mooketsi and Politsi, Limpopo Province, South Africa, from 2016 to 2018. Methods: A completely randomized block design with three replicates was used. Data were collected annually, and fruit size was classified as classes; 1 (>275 g), 2 (197-274 g), 3 (148-196 g), and 4 (0-147 g). Results: Leaf $\mathrm{N}, \mathrm{P}, \mathrm{K}, \mathrm{Ca}, \mathrm{Mg}, \mathrm{Fe}, \mathrm{Mn}, \mathrm{Na}, \mathrm{Cu}$, and $\mathrm{Zn}$, fruit yield and size distribution (\%) were significantly $(p<0.05)$ affected by compost quantity and proportionally increased with application rates in each year. Compost had cumulative effects on the measured parameters; the highest values were recorded in 2018 under a $15 \mathrm{t} \mathrm{ha}^{-1}$ application rate, which corresponded to the highest yield $\left(19.6 \mathrm{t} \mathrm{ha}^{-1}\right)$ and the largest proportion of fruits in class 1 . Conclusions: The $\geq 10 \mathrm{t} \mathrm{ha}^{-1}$ year $^{-1}$ application rate can be used, though the compost saturation levels of the soils should be determined to avoid possible danger of nutrient toxicity if high application rates are continuously used for $>3$ years.
\end{abstract}

Keywords: available nutrients; fruit quality; mineralization; nutrient absorption; plant yield

\section{Introduction}

Soil fertility management is a key factor in attaining high yield and quality in avocados [1]. The common way of maintaining soil fertility is by the use of inorganic fertilizers. Inorganic fertilizers have distinctly negative effects on the sustainability of the soil and residual effects on the harvestable plant products if poorly managed [2]. This suggests that the use of inorganic fertilizers can negatively affect crop quality's both extrinsic and intrinsic qualities. However, with the global increase in demand for organic products, many agricultural producers are moving away from inorganic fertilizers. The use of compost is one of the sustainable alternative ways of reducing the negative effects of inorganic fertilizers on the soil and crop. Compost can build up a healthy soil system by modifying all soil properties, hence attaining an increased tree performance and yield [3]. The use of organic fertilizers is on the rise, especially for international agricultural producers. Nevertheless, there is limited information on the composition of an ideal organic fertilizer that can be used without compromising soil and crop productivity. This retards the rate of organic fertilizers, especially at the commercial farming level [4]. Generally, organic fertilizers are slow-release and can steadily supply plant nutrients throughout the growing season. Most importantly, organic fertilizers such as composts have received attention from both agriculturalists and environmentalists due to their direct and indirect effects on soil properties and crop productivity [5]. 
Several studies showed varied effects of compost on soil properties, growth, and yield of different crops [5-8]. The authors of $[9,10]$ observed that composted pine bark was effective in increasing the yield and avocado fruit size. Compost is a cheap source of fertilizer and an efficient and sustainable alternative to inorganic fertilizers. Compost can affect fruit trees by enhancing nutrient uptake to supply organic acids and growthpromoting elements [6]. Compost was noted to increase root growth and reduce stress during adverse conditions, which in turn increased avocado yield [11]. The authors of [12] found that compost stimulated plant growth, root development, and thus nutrient uptake. The authors of $[11,12]$ observed that compost application, at any rate, increased the supply of nutrients and tree performance. Compost also contains a substantial amount of humic substances, which can increase shoot biomass through hormonal effects on root elongation and plant development [7]. Avocado growers are continuously in search of high yields and believe that higher yields are attainable through improving soil conditions [5].

In South African, avocado yields are within the 8-10 $\mathrm{tha}^{-1}$ range, depending on the proportion of young trees per hectare [13]. Low yields of the Hass cultivar are due to the bearing of many undersized fruits $(<200 \mathrm{~g})$, especially on nutrient-deficient soils [14,15]. However, ideally, commercial growers in the cool, semi-arid, and sub-tropics can achieve an average yield between 8 and $12 \mathrm{tha}^{-1}$ and 12 to $16 \mathrm{tha} \mathrm{h}^{-1}$ in the warmer, humid subtropics [14]. Most avocado farmers are yielding between 12 and $15 \mathrm{tha}^{-1}$ [16]; however, ZZ2 Bertie van Zyl (Pty) Ltd. has achieved $20 \mathrm{t} \mathrm{ha}^{-1}$ [17]. Yields of greater than $30 \mathrm{tha}^{-1}$ are practically achievable [15]. The authors of [16] observed that the avocado yields at ZZ2 Bertie van Zyl (Pty) Ltd. were increasing, especially under compost fertilizer application. ZZ2 Bertie van Zyl (Pty) Ltd. is still growing the Hass' avocado despite its problems of low yield, small fruit size, and alternate bearing [14]. The observations made by some researchers agreed that applying compost in combination with inorganic fertilizers improved the soil properties and yield in many crops [17]. However, when using compost fertilizer, the information on nutrient uptake by the plant and fruit yield under different soil types is unclear. Therefore, there is a challenge in soil fertility management when applying compost. Nutrient deficiency is commonly observed in the leaf and final economic yield component, hence the need to monitor the foliar nutrient content and yield.

ZZ2 Bertie van Zyl (Pty) Ltd. is migrating to the use of a sustainable organic nutrient management model in avocado production. The model promotes soil structure build-up and crop health by reducing the residual chemicals contained in the fruits. Determination of nutrient deficiency in plants is vital for the improvement of fruit yield. Leaf analysis offers the best means for diagnosing mineral nutrition problems and ultimately monitoring fertilizer use in the field [3]. The foliar nutrient content levels are greatly influenced by the type and quantity of fertilizer applied. The effects of different fertilizer types and their application rates under different soils on foliar nutrient content and yields of most crops are unclear. We hypothesized that eucalyptus compost application rate and time postapplication were important factors determining the foliar nutrient content, yield, and fruit size distribution. Therefore, this study aimed to evaluate the effect of eucalyptus-woodbased compost application rates on foliar nutrient content, yield, and fruit size distribution in two 'Hass' avocado plantations.

\section{Materials and Methods}

The study was completed at Mooketsi ( $23038^{\prime} 53.563^{\prime \prime} \mathrm{S}, 3003^{\prime} 18.964^{\prime \prime} \mathrm{E}$ and $751 \mathrm{~m}$ altitude) and Politsi ( $23045^{\prime} 56.405^{\prime \prime}$ S, $3006^{\prime} 42.264^{\prime \prime}$ E and $805 \mathrm{~m}$ altitude) avocado orchards, Limpopo Province, South Africa. The orchards fall in the subtropical, receive an annual average rainfall of $881 \mathrm{~mm}$ and $550 \mathrm{~mm}$, and an average temperature of $20.3^{\circ} \mathrm{C}$ and $20.5^{\circ} \mathrm{C}$ at Politsi and Mooketsi, respectively. The orchards were established in 2007 by grafting a 'Hass' avocado scion on a 'Dusa' rootstock. The trees were $10 \mathrm{~m} \times 5 \mathrm{~m}$ apart, each with 2 micro-sprinklers with a flow rate of $7 \mathrm{~mm}^{3} \mathrm{~s}^{-1}$ each. Irrigation was scheduled according to tensiometers that were installed in each orchard. Soil water was kept between 30 and $40 \mathrm{kpa}$ to optimize the growth of the avocado trees. Fertilizer application 
requirements were completed after the soil test. A total of $100 \mathrm{~kg} \mathrm{~N}^{-1}$ year $^{-1}$ and $55 \mathrm{~kg} \mathrm{~K} \mathrm{ha}^{-1}$ year $^{-1}$, and $170 \mathrm{~kg} \mathrm{~N} \mathrm{ha}^{-1}$ year $^{-1}$ and $53 \mathrm{~kg} \mathrm{~K} \mathrm{ha}^{-1}$ year $^{-1}$, were applied at Mooketsi and Politsi, respectively.

\subsection{Design and Experimental Treatments}

The experiments were laid in a completely randomized block design with 4 compost treatments, $0,5,10$, and $15 \mathrm{tha}^{-1}$ year $^{-1}$, replicated three times. The slope was the blocking factor. A row of 10 avocado trees represented a plot; hence, a block had 4 rows. In total, there were 3 blocks that added to 12 rows with 120 trees for the whole experiment per orchard. The median compost application rate was $10 \mathrm{t} \mathrm{ha}^{-1}$, based on the standard recommendation for organic manure remediation and soil nutrition at these selected orchards. Compost was evenly applied under the tree canopy on the soil surface using a Kuhn knight compost spreader.

\subsection{Eucalyptus Compost Preparation, Sampling, and Analysis}

The preparation and compost nutrient content was as published by [18]. Briefly, compost piles of $18 \times 2 \times 1.5 \mathrm{~m}^{3}$ in size were made on-site from locally sourced eucalyptus wood chips (40\%), sawdust (20\%), manure (20\%), and cattle manure (20\%) stock feed. The piles were turned manually after every 10 days to aerate and homogenize the compost. The moisture in the compost pile was adjusted by water so as to achieve optimum composting conditions (approximately 40-45\% moisture). The maturity of the compost was assessed on a monthly basis throughout the composting process by noting the temperature using the long probe thermometer at a depth of $60 \mathrm{~cm}$. The mature compost was tested for phytotoxicity using lettuce and onion seeds. The lettuce and onion seeds were used because they provide a good response to toxic materials and rapid germination [19]. Samples of compost were taken from four different windows at three different depths using a shovel for analysis. A total of $90 \mathrm{~mL}$ of water was mixed with $10 \mathrm{~g}$ of compost, then the compost-water mixture was shaken for $6 \mathrm{~h}$ at $25^{\circ} \mathrm{C}$ and centrifuged at $8000 \mathrm{rpm}$ for $20 \mathrm{~min}$ at $20^{\circ} \mathrm{C}$. Two sterile Petri dishes $(10 \mathrm{~cm}$ diameter each) were lined with 2 filter papers and wetted with $5 \mathrm{~mL}$ of 1:10 compost aqueous extract and control of $100 \% \mathrm{H}_{2} \mathrm{O}$. Ten seeds of either lettuce or onion were sown in the Petri dishes and incubated in the dark for 5 days at $25^{\circ} \mathrm{C}$. Germination percentage was calculated to evaluate the phytotoxicity of the compost. A 100\% germination was recorded for the lettuce and onion seeds, indicating that the compost was non-phytotoxic.

\subsection{Data Collection}

The foliar nutrient content was assessed annually from the first year of compost application in 2016 to 2018. Twenty leaves (petiole and blade) 6-8 months old were randomly picked from non-fruiting branches that had no signs of recent flushes. Leaves were collected from 4 quadrants that were randomly thrown on the 10 trees per plot. The leaves were rinsed under running $\mathrm{H}_{2} \mathrm{O}$ and washed in deionized water. After washing, the leaves were oven-dried for $24 \mathrm{~h}$ at a temperature of $65{ }^{\circ} \mathrm{C}$. After $24 \mathrm{~h}$, leaves were ground into powder, sieved through $0.250 \mathrm{~mm}$, and stored in plastic bags. Total leaf $\mathrm{N}$ was analyzed by wet digestion in micro Kjeldahl using colorimetric reading of the complex ammonia-phenol-hypochlorite [20]. A sample of $0.50 \mathrm{~g}$ of the finely grounded leaf powder was put in an oven at $60{ }^{\circ} \mathrm{C}$ and then transferred quantitatively into a $100 \mathrm{~mL}$ digestion tube. Some pumice boiling granules and $3 \mathrm{~g}$ catalyst mixtures were added to the tube. Ten milliliters of concentrated oil of vitriol was also added and stirred with a Vortex tube stirrer until it was well mixed. The tubes were then put in a block-digester set at $100{ }^{\circ} \mathrm{C}$ for $20 \mathrm{~min}$ and thoroughly agitated before being placed back on the block-digester set at $380{ }^{\circ} \mathrm{C}$ for $2 \mathrm{~h}$. After digestion, tubes were cooled, and deionized water was added to reach $100 \mathrm{~mL}$. A blank with no material and a chemical standard (0.1 g EDTA standard digest) and another with a standard plant sample (internal reference) were included. Distillation was completed by dispensing $1 \mathrm{~mL}$ saturated boric acid solution and $1 \mathrm{~mL}$ deionized water into a $100 \mathrm{~mL}$ 
pyrex evaporating dish, placed underneath the condenser with the tip touching the answer surface. A total of $10 \mathrm{~mL}$ of aliquot was transferred into a $100 \mathrm{~mL}$ distillation flask, wherein $10 \mathrm{~mL}$ of $10 \mathrm{~N}$ caustic soda solution was carefully added and immediately connected to the flask to the distillation unit. The distillation flask was removed and connected to an empty $100 \mathrm{~mL}$ distillation flask attached to the distillation unit. The distillate was titrated to $\mathrm{pH} 5$ with standardized $0.01 \mathrm{~N}$ vitriol using an Auto-Titrator, and a titrated volume of acid was recorded.

Leaf $\mathrm{P}, \mathrm{K}, \mathrm{Ca}, \mathrm{Mg}, \mathrm{Na}, \mathrm{Fe}, \mathrm{Mn}, \mathrm{Zn}$, and $\mathrm{Cu}$ were determined by the dry ash method. One gram of dry leaf sample was transferred into a $50 \mathrm{~mL}$ porcelain crucible. The porcelain crucible was placed into a cool muffle furnace, and thereafter the temperature was gradually increased to $550{ }^{\circ} \mathrm{C}$ and continued burning for $5 \mathrm{~h}$ at $550{ }^{\circ} \mathrm{C}$. The cooled ash was dissolved into $5 \mathrm{~mL}$ portions of $2 \mathrm{~N}$ acid and mixed using a plastic rod. After $20 \mathrm{~min}$, the mixture was diluted to $50 \mathrm{~mL}$ with deionized water. The contents were thoroughly mixed and allowed to square off for half-hour. The content was then filtered through Whatman number 42 paper. The aliquot was analyzed for $\mathrm{P}$ by Colorimetric method, K and Na by Flame Photometry, and $\mathrm{Ca}, \mathrm{Mg}, \mathrm{Zn}, \mathrm{Cu}, \mathrm{Fe}$, and $\mathrm{Mn}$ by Atomic Absorption Spectroscopy [20].

Avocado yield and fruit size distribution data were collected during the conventional harvesting period. The avocado fruits were picked from April to May each year, and the fruits were picked from 10 representative trees of every replicate. Fruits from each tree were picked, the number of lugs full avocados counted and weighed using an analytical scale. The yield was computed to a lot per hectare using the formula:

$$
\text { Yield }=\sum(y-\alpha) /(x \times n) \beta
$$

where $y=$ the number of crates harvested per replicate $(\mathrm{kg} /$ replicate $), x=$ the space occupied by one plant $\left(50 \mathrm{~m}^{2}\right), n=$ the number of trees per replicate (10), $\alpha=$ converts weight into $\mathrm{kg}$ to $\mathrm{t}(10-6)$, and $\beta=$ converts area in $\mathrm{m}^{2}$ to ha (10-4).

Fruit size distributions were determined by weighing individual fruits from four representative crates of every tree for every replicate. Fruit size distribution was classified as class 1 (>275 g), class 2 (197-274 g), class 3 (148-196 g), and class 4 (0-147 g).

\subsection{Data Analysis}

Analysis of variance (ANOVA) to determine the effects of the eucalyptus-based compost application rates on the leaf nutrient content, yield, and fruit distribution size was completed using Statistix software version 10.0. Means were separated using Tukey's honestly significant difference (HSD) test $(a=0.05)$. Leaf nutrient level results obtained from Mooketsi and Politsi after applying compost at different rates were categorized using critical soil nutrient limits for avocado production adopted by [21] (Table 1). 
Table 1. Important leaf nutrients categories for avocado production in South Africa.

\begin{tabular}{|c|c|c|c|c|c|}
\hline \multirow[t]{2}{*}{ Nutrient Element } & \multirow[t]{2}{*}{ Unit } & \multicolumn{3}{|c|}{ Ranges for Mature Avocado Trees } & \multirow[t]{2}{*}{ Reference } \\
\hline & & Low & Sufficient & High & \\
\hline $\mathrm{N}$ & $(\%)$ & $<1.8$ & $2.0-2.2$ & $>2.2$ & Whiley et al., 1996 \\
\hline $\mathrm{P}$ & $(\%)$ & $0.05-0.09$ & $0.10-0.25$ & $0.26-0.3$ & Lahav and Kadman, 1980 \\
\hline $\mathrm{K}$ & $(\%)$ & $0.34-0.74$ & $0.75-2.0$ & $2.1-2.9$ & Lahav and Kadman, 1980 \\
\hline $\mathrm{Ca}$ & $(\%)$ & $0.50-0.99$ & $1.00-3.00$ & $3.1-4.0$ & Whiley et al., 1996; Lahav and Kadman, 1980 \\
\hline $\mathrm{Mg}$ & $(\%)$ & $0.15-0.24$ & $0.25-0.80$ & $0.9-1.0$ & Whiley et al., 1996; Lahav and Kadman, 1980 \\
\hline $\mathrm{Mn}$ & $(\%)$ & $0.015-0.029$ & $0.030-0.050$ & $>0.0500$ & Whiley et al., 1996; Lahav and Kadman, 1980 \\
\hline $\mathrm{Fe}$ & $(\%)$ & $0.020-0.049$ & 0.20 & $>0.200$ & Whiley et al., 1996; Lahav and Kadman, 1980 \\
\hline $\mathrm{Zn}$ & $(\%)$ & $<0.020$ & $0.030-0.035$ & $>0.035$ & Whiley et al., 1996; Lahav and Kadman, 1980 \\
\hline $\mathrm{Cu}$ & $(\%)$ & $<0.05$ & $0.05-0.065$ & $>0.065$ & Whiley et al., 1996; Lahav and Kadman, 1980 \\
\hline $\mathrm{Na}$ & $(\%)$ & - & - & $0.05-0.19$ & Whiley et al., 1996; Lahav and Kadman, 1980 \\
\hline
\end{tabular}

Adapted from boron nutrition of avocados [21], with permission from South Africa Avocado Grower's Association, 1996.

\section{Results}

There were significant $(p<0.05)$ interactions between the eucalyptus-wood-based compost application rates $(\mathrm{R}) \times$ time $(\mathrm{Y})$ and avocado yield $\left(\mathrm{t} \mathrm{ha}{ }^{-1}\right)$, fruit size, and foliar nutrient content at both the Mooketsi and Politsi orchards (Table 2).

Table 2. ANOVA for yield, fruit size, and foliar nutrient element content following a 3-year application of the eucalyptus-wood-based compost at the Mooketsi and Politsi orchards.

\begin{tabular}{|c|c|c|c|c|c|c|c|c|c|c|c|c|c|}
\hline \multicolumn{14}{|c|}{ Mooketsi Orchard } \\
\hline \multicolumn{2}{|l|}{ Source of Variation } & Yield & Fruit Size & \multirow{2}{*}{$\begin{array}{c}\mathbf{N} \\
1.31\end{array}$} & \multirow{2}{*}{$\begin{array}{c}\mathbf{P} \\
1.58\end{array}$} & \multirow{2}{*}{$\begin{array}{c}\mathbf{K} \\
1.05\end{array}$} & \multirow{2}{*}{$\begin{array}{c}\mathrm{Ca} \\
3.11\end{array}$} & \multirow{2}{*}{$\frac{\mathbf{M g}}{1.35}$} & $\mathrm{Na}$ & Mn & $\mathrm{Cu}$ & $\mathrm{Zn}$ & $\mathrm{Fe}$ \\
\hline Compost rate (R) & $F_{\text {prob. }}$ & 2.10 & 4.33 & & & & & & 1.05 & 2.17 & 1.36 & 1.36 & 1.15 \\
\hline \multirow{3}{*}{ Time (Y) } & $p$ & 0.01 & 0.03 & $<0.01$ & $<0.01$ & 0.01 & 0.02 & 0.02 & $<0.01$ & $<0.01$ & 0.01 & 0.01 & 0.01 \\
\hline & $F_{\text {prob. }}$ & 1.32 & 2.30 & 2.10 & 1.37 & 1.12 & 2.15 & 0.62 & 0.60 & 1.50 & 6.12 & 3.16 & 3.16 \\
\hline & $p$ & $<0.01$ & 0.01 & 0.02 & $<0.01$ & 0.02 & $<0.01$ & 0.01 & 0.03 & $<0.01$ & $<0.01$ & $<0.01$ & $<0.01$ \\
\hline \multirow[t]{2}{*}{$\mathrm{R} \times \mathrm{Y}$} & $F_{\text {prob. }}$ & 1.71 & 2.07 & 1.92 & 2.21 & 1.31 & 2.23 & 1.12 & 1.12 & 2.42 & 1.34 & 2.33 & 1.31 \\
\hline & $p$ & 0.02 & 0.01 & 0.03 & 0.02 & 0.01 & $<0.01$ & $<0.01$ & 0.03 & $<0.01$ & 0.01 & 0.01 & 0.01 \\
\hline \multirow{3}{*}{$\begin{array}{l}\text { Politsi Orchard } \\
\text { Compost rate (R) }\end{array}$} & & & & & & & & & & & & & \\
\hline & $F_{\text {prob. }}$ & 2.13 & 1.30 & 1.20 & 1.19 & 1.10 & 2.44 & 1.18 & 1.13 & 3.43 & 2.30 & 1.46 & 0.83 \\
\hline & $p$ & $<0.01$ & $<0.01$ & $<0.01$ & $<0.01$ & $<0.01$ & 0.01 & 0.02 & $<0.01$ & $<0.01$ & $<0.01$ & $<0.01$ & $<0.01$ \\
\hline \multirow[t]{2}{*}{ Time (Y) } & $F_{\text {prob. }}$ & 2.16 & 1.76 & 2.00 & 1.12 & 1.56 & 1.76 & 0.65 & 1.30 & 2.27 & 1.41 & 3.17 & 2.55 \\
\hline & $p$ & 0.01 & 0.01 & $<0.01$ & 0.04 & 0.01 & 0.01 & $<0.01$ & $<0.01$ & $<0.01$ & 0.01 & 0.01 & 0.02 \\
\hline \multirow[t]{2}{*}{$\mathrm{R} \times \mathrm{Y}$} & $F_{\text {prob. }}$ & 2.04 & 2.16 & 3.18 & 4.29 & 1.14 & 2.54 & 1.03 & 2.28 & 1.48 & 5.25 & 2.10 & 3.20 \\
\hline & $p$ & $<0.01$ & 0.01 & 0.01 & $<0.01$ & 0.01 & $<0.01$ & $<0.01$ & 0.01 & $<0.01$ & $<0.01$ & $<0.01$ & $<0.01$ \\
\hline
\end{tabular}

\subsection{Leaf Macronutrients ( $N, P, K, C a$, and $M g$ )}

At the Mooketsi orchard, leaf nitrogen $(\mathrm{N})$ was significantly $(p>0.05)$ different between $0 \mathrm{tha} \mathrm{h}^{-1}$ and $10 \mathrm{t} \mathrm{ha}^{-1}$ and $0 \mathrm{tha} \mathrm{h}^{-1}$ and $15 \mathrm{tha}^{-1}$ compost application rates each year. However, there was no significant difference in leaf $\mathrm{N}$ concentration between $0 \mathrm{tha}^{-1}$ and $5 \mathrm{tha}^{-1}, 5 \mathrm{tha}^{-1}$ and $10 \mathrm{tha}^{-1}$, and $10 \mathrm{tha}^{-1}$ and $15 \mathrm{tha}^{-1}$ application rates (Table 3). The highest $(3.15 \%)$ and lowest $(0.71 \%)$ leaf $\mathrm{N}$ were observed under $15 \mathrm{tha}^{-1}$ and $0 \mathrm{t} \mathrm{ha}^{-1}$ in 2018 , respectively. P was not significantly $(p>0.05)$ different among the eucalyptus-woodbased compost application rates for the entire study period (Table 3). Potassium (K) was significant $(p>0.05)$ different between $0 \mathrm{tha}^{-1}$ and $15 \mathrm{tha}^{-1}$ in all three years: $0 \mathrm{tha}^{-1}$ and $10 \mathrm{t} \mathrm{ha}^{-1}$ in 2017 and 2018, and $0 \mathrm{t} \mathrm{ha}^{-1}$ and $5 \mathrm{t} \mathrm{ha}^{-1}$ in 2018 only (Table 3). Leaf Ca varied significantly $(p<0.05)$ depending on the quantity of the eucalyptus-wood-based compost applied in each year. Leaf Mg levels were significantly $(p<0.05)$ different among the eucalyptus-wood-based compost between $0 \mathrm{tha}^{-1}$ and $10 \mathrm{t} \mathrm{ha}^{-1}$ and $0 \mathrm{tha} \mathrm{h}^{-1}$ and $15 \mathrm{t} \mathrm{ha}^{-1}$ from 2017 to 2018. Significant differences in $\mathrm{Mg}$ were also observed in 2018 between $0 \mathrm{tha}^{-1}$ and $5 \mathrm{tha}^{-1}$ (Table 3). The highest (3.08\%) and lowest $(0.60 \%)$ leaf $\mathrm{Ca}$ 
were observed under $15 \mathrm{t} \mathrm{ha}^{-1}$ and $0 \mathrm{t} \mathrm{ha}^{-1}$ in 2018, respectively. $\mathrm{K}$ and Mg were lowest and highest in 2018 under $0 \mathrm{t} \mathrm{ha}^{-1}$ and $15 \mathrm{tha}^{-1}$ application rates, respectively (Table 3).

At the Politsi orchard, the leaf concentrations of $\mathrm{N}, \mathrm{P}, \mathrm{K}, \mathrm{Ca}$, and $\mathrm{Mg}$ followed a similar trend that was observed at the Mooketsi orchard (Table 3). Foliar P was not significantly $(p<0.05)$ different in all the eucalyptus-wood-based compost application rates from 2016 to 2018. The highest (3.10\%) and lowest $(0.70 \%)$ leaf Ca were observed under $15 \mathrm{t} \mathrm{ha}^{-1}$ and $0 \mathrm{t} \mathrm{ha}^{-1}$ in 2018, respectively. $\mathrm{K}$ and $\mathrm{Mg}$ concentrations were also lowest and highest in 2018 under $0 \mathrm{t} \mathrm{ha}^{-1}$ and $15 \mathrm{tha}^{-1}$ application rates, respectively (Table 3 ).

\subsection{Leaf Micronutrients ( $\mathrm{Fe}, \mathrm{Mn}, \mathrm{Na}, \mathrm{Cu}$, and $\mathrm{Zn}$ )}

The foliar $\mathrm{Fe}, \mathrm{Mn}, \mathrm{Na}, \mathrm{Cu}$, and $\mathrm{Zn}$ concentrations varied significantly $(p<0.05)$ among the eucalyptus-wood-based application rates from 2016 to 2018 at both Mooketsi and Politsi orchards (Table 4). The leaf $\mathrm{Na}$ and $\mathrm{Cu}$ concentrations were not affected by the addition of the eucalyptus-wood-based compost at both orchards throughout the study period. However, leaf $\mathrm{Fe}, \mathrm{Zn}$, and $\mathrm{Mn}$ concentrations were significantly affected by the $10 \mathrm{tha}^{-1}$ and $15 \mathrm{tha}^{-1}$ eucalyptus-wood-based application rates (Table 4). At the Mooketsi and Politsi orchards, the lowest and highest leaf $\mathrm{Fe}, \mathrm{Mn}$, and $\mathrm{Zn}$ concentrations were noted in 2018 under $0 \mathrm{t} \mathrm{ha}^{-1}$ and $15 \mathrm{tha}^{-1}$ compost application rates, respectively (Table 4$)$. At the Mooketsi orchard, the lowest $(0.089 \%$ and $0.18 \%)$ and highest $(0.209 \%$ and $0.63 \%)$ leaf Fe and $\mathrm{Zn}$ were noted in 2018 under $0 \mathrm{t} \mathrm{ha}^{-1}$ and $15 \mathrm{tha}^{-1}$ compost application rates, respectively (Table 4$)$, whereas at the Politsi orchard, the lowest $(0.081 \%$ and $0.16 \%)$ and highest $(0.206 \%$ and $0.65 \%)$ leaf Fe and $\mathrm{Zn}$ were noted in 2018 under $0 \mathrm{t} \mathrm{ha}^{-1}$ and $15 \mathrm{tha}^{-1}$ compost application rates, respectively (Table 4).

\subsection{Avocado Fruit Yield}

The avocado yield $\left(\mathrm{t} \mathrm{ha}^{-1}\right)$ varied significantly $(p<0.05)$ among the eucalyptus-woodbased compost application rates at both orchards (Table 5). The highest $\left(19.9 \mathrm{t} \mathrm{ha}^{-1}\right)$ and lowest $\left(4.5 \mathrm{t} \mathrm{ha}^{-1}\right)$ yields were observed in 2018 at the Mooketsi orchard, whereas the highest $\left(19.4 \mathrm{t} \mathrm{ha}^{-1}\right)$ and lowest $\left(3.6 \mathrm{tha}^{-1}\right)$ yields were recorded at the Politsi orchard (Table 5).

\subsection{Avocado Fruit Size Distribution}

Avocado fruit size distribution (\%) was influenced by the eucalyptus-wood-based compost application rates. The lower the compost application rate, the more fruits were in class 4 and 3 categories at both the Mooketsi and Politsi orchards (Table 6). The $15 \mathrm{tha}^{-1}$ compost application rate had the most fruits in class 1 and the least fruits in class 4 , while the $0 \mathrm{t} \mathrm{ha}^{-1}$ compost application rate recorded the most fruits in class 4 and the least in the class 1 category at both orchards (Table 6). 
Table 3. Leaf macronutrients (N, P, K, Ca, and Mg) contents as influenced by compost application rates over a three-year study (2016-2018) at Mooketsi and Politsi orchards.

\begin{tabular}{|c|c|c|c|c|c|c|c|c|c|c|c|c|c|c|c|}
\hline \multicolumn{16}{|c|}{ Mooketsi Orchard } \\
\hline Treatment & & $\mathrm{N}$ & & & $\mathbf{P}$ & & & $\mathrm{K}$ & & & $\mathrm{Ca}$ & & & $\mathrm{Mg}$ & \\
\hline \multicolumn{16}{|c|}{$\%$} \\
\hline & 2016 & 2017 & 2018 & 2016 & 2017 & 2018 & 2016 & 2017 & 2018 & 2016 & 2017 & 2018 & 2016 & 2017 & 2018 \\
\hline 0 tha $^{-1}$ & $1.20^{\mathrm{a}}$ & $1.06^{\mathrm{a}}$ & $0.71^{\mathrm{a}}$ & 0.17 & 0.10 & 0.18 & $0.92^{a}$ & $0.80^{\mathrm{a}}$ & $0.72^{\mathrm{a}}$ & $0.80^{\mathrm{a}}$ & $0.74^{\mathrm{a}}$ & $0.60^{\mathrm{a}}$ & 0.62 & $0.45^{\mathrm{a}}$ & $0.43^{\mathrm{a}}$ \\
\hline $5 \mathrm{tha}^{-1}$ & $2.44^{\mathrm{b}}$ & $2.60^{\mathrm{b}}$ & $2.93^{\mathrm{a}}$ & 0.18 & 0.21 & 0.36 & $1.47^{\mathrm{a}}$ & $2.14^{\mathrm{b}}$ & $2.22^{b}$ & $0.95^{\mathrm{a}}$ & $0.96^{\mathrm{a}}$ & $1.88^{\mathrm{b}}$ & 0.75 & $0.72^{\mathrm{a}}$ & $0.90^{\mathrm{b}}$ \\
\hline $10 \mathrm{tha}^{-1}$ & $2.46^{\mathrm{b}}$ & $2.62^{\mathrm{b}}$ & $3.09^{b}$ & 0.17 & 0.27 & 0.58 & $1.44^{\mathrm{a}}$ & $2.48^{\mathrm{b}}$ & $2.20^{\mathrm{b}}$ & $1.66^{\mathrm{b}}$ & $2.54^{\mathrm{b}}$ & $2.94^{\mathrm{c}}$ & 0.83 & $1.11^{\mathrm{ab}}$ & $1.10^{\mathrm{b}}$ \\
\hline $15 \mathrm{tha}^{-1}$ & $2.49^{\mathrm{b}}$ & $2.71^{\mathrm{b}}$ & $3.15^{\mathrm{b}}$ & 0.18 & 0.31 & 0.66 & $1.65^{\mathrm{b}}$ & $2.50^{\mathrm{b}}$ & $2.23^{\mathrm{b}}$ & $1.78^{\mathrm{b}}$ & $2.73^{\mathrm{b}}$ & $3.08^{\mathrm{c}}$ & 0.90 & $1.24^{\mathrm{b}}$ & $1.18^{\mathrm{b}}$ \\
\hline HSD & 0.91 & 1.02 & 1.43 & 0.56 & 0.57 & 0.68 & 0.71 & 0.65 & 0.73 & 0.68 & 0.97 & 1.04 & 0.54 & 0.44 & 0.40 \\
\hline \multicolumn{16}{|c|}{ Politsi Orchard } \\
\hline 0 tha $^{-1}$ & $1.21^{\mathrm{a}}$ & $1.00^{\mathrm{a}}$ & $0.82^{a}$ & 0.14 & 0.13 & 0.11 & 0.83 & $0.70^{\mathrm{a}}$ & $0.63^{\mathrm{a}}$ & $0.70^{\mathrm{a}}$ & $0.81^{\mathrm{a}}$ & $0.80^{\mathrm{a}}$ & 0.36 & $0.33^{\mathrm{a}}$ & $0.29 \mathrm{a}$ \\
\hline $5 \mathrm{tha}^{-1}$ & $2.42^{\mathrm{b}}$ & $2.82^{\mathrm{b}}$ & $2.93^{\mathrm{b}}$ & 0.15 & 0.27 & 0.36 & 1.06 & $1.64^{\mathrm{b}}$ & $1.71^{\mathrm{b}}$ & $0.96^{\mathrm{a}}$ & $0.98^{\mathrm{a}}$ & $1.90^{\mathrm{b}}$ & 0.45 & $0.56^{\mathrm{a}}$ & $0.60^{\mathrm{b}}$ \\
\hline $10 \mathrm{tha}^{-1}$ & $2.49^{\mathrm{b}}$ & $2.71^{\mathrm{b}}$ & $2.98^{\mathrm{b}}$ & 0.16 & 0.28 & 0.59 & 1.14 & $1.86^{\mathrm{b}}$ & $1.94^{\mathrm{b}}$ & $1.62^{\mathrm{b}}$ & $2.58^{\mathrm{b}}$ & $2.90^{\mathrm{c}}$ & 0.53 & $0.95^{\mathrm{ab}}$ & $0.87^{\mathrm{b}}$ \\
\hline $15 \mathrm{tha}^{-1}$ & $2.46^{\mathrm{b}}$ & $2.87^{\mathrm{b}}$ & $3.16^{\mathrm{b}}$ & 0.17 & 0.30 & 0.65 & 1.13 & $1.94^{\mathrm{b}}$ & $2.15^{\mathrm{b}}$ & $1.76^{\mathrm{b}}$ & $2.65^{\mathrm{b}}$ & $3.10^{\mathrm{d}}$ & 0.55 & $1.02^{\mathrm{b}}$ & $0.86^{\mathrm{b}}$ \\
\hline HSD & 1.01 & 1.00 & 1.41 & 0.46 & 0.55 & 0.65 & 0.68 & 0.62 & 0.91 & 0.61 & 1.01 & 0.98 & 0.58 & 0.43 & 0.46 \\
\hline
\end{tabular}

Values followed by the same letter in a column do not differ significantly $(p<0.05)$.

Table 4. Leaf Fe, Mn, Na, Cu, and Zn contents as influenced by compost application rates over a three-year study (2016-2018) at the Mooketsi and Politsi orchards.

\begin{tabular}{|c|c|c|c|c|c|c|c|c|c|c|c|c|c|c|c|}
\hline \multicolumn{16}{|c|}{ Mooketsi Orchard } \\
\hline Treatment & & $\mathrm{Fe}$ & & & Mn & & & $\mathrm{Na}$ & & & $\mathrm{Cu}$ & & & $\mathrm{Zn}$ & \\
\hline \multicolumn{16}{|c|}{$\%$} \\
\hline & 2016 & 2017 & 2018 & 2016 & 2017 & 2018 & 2016 & 2017 & 2018 & 2016 & 2017 & 2018 & 2016 & 2017 & 2018 \\
\hline $0 \mathrm{tha}^{-1}$ & 0.136 & 0.112 & 0.089 a & 0.252 & $0.235^{\mathrm{a}}$ & $0.136^{\mathrm{a}}$ & 0.039 & 0.026 & $0.028^{a}$ & 0.028 & 0.021 & 0.016 & $0.27^{\mathrm{a}}$ & $0.21^{\mathrm{a}}$ & $0.18^{\mathrm{a}}$ \\
\hline 5 tha $^{-1}$ & 0.145 & 0.151 & $0.170^{\mathrm{b}}$ & 0.265 & $0.273^{b}$ & $0.286^{\mathrm{b}}$ & 0.045 & 0.057 & $0.091^{\mathrm{b}}$ & 0.039 & 0.040 & 0.049 & $0.36^{\mathrm{b}}$ & $0.48^{\mathrm{b}}$ & $0.53^{\mathrm{b}}$ \\
\hline $10 \mathrm{tha}^{-1}$ & 0.149 & 0.179 & $0.192^{b}$ & 0.289 & $0.293^{b}$ & $0.310^{\mathrm{b}}$ & 0.047 & 0.063 & $0.096^{\mathrm{b}}$ & 0.041 & 0.043 & 0.048 & $0.38^{\mathrm{b}}$ & $0.49^{\mathrm{b}}$ & $0.59 \mathrm{bc}$ \\
\hline $15 \mathrm{tha}^{-1}$ & 0.150 & 0.193 & $0.209^{b}$ & 0.297 & $0.312^{\mathrm{b}}$ & $0.336^{\mathrm{b}}$ & 0.049 & 0.070 & $0.099^{b}$ & 0.045 & 0.043 & 0.047 & $0.40^{\mathrm{b}}$ & $0.52^{\mathrm{b}}$ & $0.63^{\mathrm{c}}$ \\
\hline HSD & 0.075 & 0.061 & 0.064 & 0.068 & 0.070 & 0.081 & 0.040 & 0.032 & 0.034 & 0.030 & 0.032 & 0.036 & 0.06 & 0.062 & 0.06 \\
\hline $0 \mathrm{tha}^{-1}$ & 0.142 & 0.110 & $0.081^{\mathrm{a}}$ & 0.256 & $0.238^{\mathrm{a}}$ & $0.130^{\mathrm{a}}$ & 0.035 & 0.026 & $0.019^{a}$ & 0.029 & 0.027 & 0.014 & $0.26^{a}$ & $0.21^{\mathrm{a}}$ & $0.16^{\mathrm{a}}$ \\
\hline $5 \mathrm{tha}^{-1}$ & 0.151 & 0.160 & $0.171^{\mathrm{b}}$ & 0.268 & $0.276^{\mathrm{b}}$ & $0.279^{b}$ & 0.046 & 0.055 & $0.096^{\mathrm{b}}$ & 0.035 & 0.041 & 0.058 & $0.36^{\mathrm{b}}$ & $0.40^{\mathrm{b}}$ & $0.51^{\mathrm{b}}$ \\
\hline $10 \mathrm{tha}^{-1}$ & 0.149 & 0.163 & $0.188^{b}$ & 0.285 & $0.294^{\mathrm{b}}$ & $0.292^{b}$ & 0.049 & 0.068 & $0.093^{b}$ & 0.041 & 0.054 & 0.065 & $0.41^{\mathrm{b}}$ & $0.53^{\mathrm{b}}$ & $0.58^{\mathrm{ab}}$ \\
\hline $15 \mathrm{tha}^{-1}$ & 0.150 & 0.167 & $0.206^{\mathrm{b}}$ & 0.298 & $0.318^{\mathrm{b}}$ & $0.335^{\mathrm{b}}$ & 0.049 & 0.074 & $0.098^{\mathrm{b}}$ & 0.047 & 0.063 & 0.074 & $0.45^{\mathrm{b}}$ & $0.57^{\mathrm{b}}$ & $0.62^{c}$ \\
\hline HSD & 0.074 & 0.060 & 0.065 & 0.065 & 0.072 & 0.075 & 0.086 & 0.085 & 0.084 & 0.071 & 0.074 & 0.075 & 0.062 & 0.063 & 0.062 \\
\hline
\end{tabular}


Table 5. Effects of the eucalyptus-wood-based compost application rates on avocado fruit yield during the three-year study (2016-2018) at Mooketsi and Politsi orchards.

\begin{tabular}{|c|c|c|c|c|}
\hline & \multirow[t]{2}{*}{ Treatments } & \multicolumn{3}{|c|}{ Avocado Fruit Yield ( $\mathrm{ha}{ }^{-1}$ ) } \\
\hline & & 2016 & 2017 & 2018 \\
\hline \multirow[t]{2}{*}{ Mooketsi orchard } & $\begin{array}{l}0 \mathrm{tha}^{-1} \\
5 \mathrm{tha}^{-1} \\
10 \mathrm{tha}^{-1} \\
15 \mathrm{tha}^{-1}\end{array}$ & $\begin{array}{c}6.4^{\mathrm{a}} \\
8.1^{\mathrm{b}} \\
9.8^{\mathrm{c}} \\
10.2^{\mathrm{d}} \\
\end{array}$ & $\begin{array}{c}5.9^{\mathrm{a}} \\
12.6^{\mathrm{b}} \\
13.6^{\mathrm{c}} \\
14.2^{\mathrm{d}}\end{array}$ & $\begin{array}{r}4.5^{\mathrm{a}} \\
13.7^{\mathrm{b}} \\
18.7^{\mathrm{c}} \\
19.9^{\mathrm{d}}\end{array}$ \\
\hline & HSD & 0.94 & 0.92 & 0.91 \\
\hline \multirow[t]{2}{*}{ Politsi orchard } & $\begin{array}{l}0 \mathrm{tha}^{-1} \\
5 \mathrm{tha}^{-1} \\
10 \mathrm{tha}^{-1} \\
15 \mathrm{tha}^{-1}\end{array}$ & $\begin{array}{l}6.0^{\mathrm{a}} \\
7.9^{\mathrm{b}} \\
9.1^{\mathrm{c}} \\
9.9^{\mathrm{d}} \\
\end{array}$ & $\begin{array}{r}4.9^{\mathrm{a}} \\
11.9^{\mathrm{b}} \\
12.8^{\mathrm{c}} \\
15.7^{\mathrm{d}} \\
\end{array}$ & $\begin{array}{c}3.6^{\mathrm{a}} \\
13.5^{\mathrm{b}} \\
17.8^{\mathrm{c}} \\
19.4^{\mathrm{d}}\end{array}$ \\
\hline & HSD & 0.93 & 0.91 & 0.91 \\
\hline
\end{tabular}

Values followed by the same letter in a column do not differ significantly $(p<0.05)$.

Table 6. Avocado fruit size distribution (\%) as influenced by compost application rates over the three-year study (2016-2018) at the Mooketsi and Politsi orchards.

\begin{tabular}{|c|c|c|c|c|c|c|c|c|c|c|c|c|}
\hline \multicolumn{13}{|c|}{ Mooketsi Orchard } \\
\hline \multirow[t]{2}{*}{ Treatment } & \multicolumn{3}{|c|}{ Class 1 (>274 g) } & \multicolumn{3}{|c|}{ Class 2 (197-274 g) } & \multicolumn{3}{|c|}{ Class 3 (148-196 g) } & \multicolumn{3}{|c|}{ Class $4(0-147 \mathrm{~g})$} \\
\hline & 2016 & 2017 & 2018 & 2016 & 2017 & 2018 & 2016 & 2017 & 2018 & 2016 & 2017 & 2018 \\
\hline $0 \mathrm{tha}^{-1}$ & $4.3^{\mathrm{a}}$ & $3.3^{\mathrm{a}}$ & $0.8^{\mathrm{a}}$ & $9.2^{\mathrm{a}}$ & $7.3^{\mathrm{a}}$ & $5.7^{\mathrm{a}}$ & $38.0^{\mathrm{a}}$ & $20.0^{\mathrm{a}}$ & $15.0^{\mathrm{a}}$ & $40.7^{\mathrm{a}}$ & $45.5^{\mathrm{a}}$ & $56.6^{\mathrm{a}}$ \\
\hline $10 \mathrm{tha}^{-1}$ & $26.0^{\mathrm{b}}$ & $27.7^{\mathrm{b}}$ & $28.2^{\mathrm{b}}$ & $26.7^{c}$ & $27.0^{\mathrm{c}}$ & $30.0^{\mathrm{c}}$ & $21.0^{\mathrm{b}}$ & $26.3^{b c}$ & $27.3^{b c}$ & $20.0^{\mathrm{c}}$ & $14.1^{\mathrm{c}}$ & $11.3^{\mathrm{c}}$ \\
\hline $15 \mathrm{tha}^{-1}$ & $44.4^{\mathrm{b}}$ & $43.0^{\mathrm{b}}$ & $44.0^{\mathrm{b}}$ & $20.2^{\mathrm{c}}$ & $19.6^{\mathrm{c}}$ & $18.0^{\mathrm{c}}$ & $9.0^{\mathrm{c}}$ & $21.4^{\mathrm{c}}$ & $22.4^{\mathrm{c}}$ & $9.3^{\mathrm{d}}$ & $7.9^{\mathrm{c}}$ & $7.3^{c}$ \\
\hline HSD & 19.6 & 21.4 & 17.2 & 13.4 & 12.6 & 11.7 & 10.8 & 9.5 & 8.3 & 7.1 & 6.3 & 7.4 \\
\hline \multicolumn{13}{|c|}{ Politsi Orchard } \\
\hline $5 \mathrm{tha}^{-1}$ & $24.3^{\mathrm{b}}$ & $25.0^{\mathrm{b}}$ & $25.4^{\mathrm{b}}$ & $42.0^{\mathrm{b}}$ & $44.3^{\mathrm{b}}$ & $45.3^{\mathrm{b}}$ & $33.0^{\mathrm{a}}$ & $30.6^{\mathrm{b}}$ & $35.3^{\mathrm{b}}$ & $32.5^{\mathrm{b}}$ & $35.4^{\mathrm{b}}$ & $25.2^{\mathrm{b}}$ \\
\hline $10 \mathrm{tha}^{-1}$ & $27.0^{\mathrm{b}}$ & $27.9^{\mathrm{b}}$ & $28.8^{\mathrm{b}}$ & $28.7^{c}$ & $27.8^{\mathrm{c}}$ & $29.5^{c}$ & $22.9^{\mathrm{b}}$ & $27.3^{b c}$ & $28.3^{b c}$ & $19.5^{\mathrm{c}}$ & $14.0^{\mathrm{c}}$ & $12.6^{\mathrm{c}}$ \\
\hline $15 \mathrm{tha}^{-1}$ & $43.4^{\mathrm{b}}$ & $43.0^{\mathrm{b}}$ & $44.2^{\mathrm{b}}$ & $21.1^{\mathrm{c}}$ & $20.6^{\mathrm{c}}$ & $19.0^{\mathrm{c}}$ & $7.6^{\mathrm{c}}$ & $21.1^{\mathrm{c}}$ & $22.0^{\mathrm{c}}$ & $9.0^{\mathrm{d}}$ & $8.0^{\mathrm{c}}$ & $6.8^{\mathrm{c}}$ \\
\hline HSD & 18.3 & 20.1 & 16.5 & 12.4 & 10.7 & 9.3 & 11.1 & 8.4 & 7.9 & 6.8 & 7.0 & 6.9 \\
\hline
\end{tabular}

Values followed by the same letter in a column do not differ significantly $(p<0.05)$. 


\section{Discussion}

\subsection{Leaf Macronutrients ( $\mathrm{N}, \mathrm{P}, \mathrm{K}, \mathrm{Ca}$, and $\mathrm{Mg}$ )}

At Mooketsi and Politsi orchards, the leaf $\mathrm{N}$ levels were significantly $(p<0.05)$ increasing with an increase in the eucalyptus-wood-based application rates from 2016 to 2018. In this study, the leaf $\mathrm{N}$ levels were $>1.8 \%$ under all compost-amended plots, which indicated that the $\mathrm{N}$ supplied to the soil was adequate for the plants. Application of eucalyptus-wood-based compost at $>0 \mathrm{t} \mathrm{ha}^{-1}$ resulted in high $(>2.22 \%)$ leaf $\mathrm{N}$ levels at both orchards. This suggests that the application of the eucalyptus-wood-based compost at $\geq 5 \mathrm{tha}^{-1}$ could supply adequate $\mathrm{N}$ to the plants [21], and no visual symptoms of $\mathrm{N}$ deficiency are expected. The authors of [17] also found that leaf $\mathrm{N}$ levels below $1.6 \%$ and higher than $2.0 \%$ were associated with a drop in fruit production, though the yield levels obtained in this study do not confirm these dropping effects. However, this relationship has not been obtained in some avocado cultivars in spite of the numerous nutritional work completed in many avocado production areas, such as [22,23].

Leaf K levels were significantly $(p<0.05)$ increasing with an increase in the eucalyptuswood-based compost applied at both orchards. Leaf $\mathrm{K}$ levels were $<0.74 \%$ under $0 \mathrm{tha}^{-1}$ but were $>0.74 \%$ at $>0 \mathrm{tha}^{-1}$ compost application rates at both orchards. This suggests that there was a $\mathrm{K}$ deficiency in compost-unamended plots at the orchards. The $\mathrm{K}$ levels below $0.74 \%$ in 5-7 months-old leaves are considered dangerously low for avocado production. Nitrogen $(\mathrm{N})$ and potassium $(\mathrm{K})$ are of great importance in avocado nutrition based on the amounts needed. In most cases, $\mathrm{N}$ is more likely to become deficient than $\mathrm{K}$ in avocado orchards, especially when no supplementary fertilization is completed.

The $P$ element is well known to be essential for vigorous young plants, but its relative importance declined as the avocado tree growth rate slowed down. Thus, the amount of phosphorus $(\mathrm{P})$ needed for trees in production is relatively small, where the high leaf content should range around $0.26-0.3 \%$. Leaf $P$ levels in trees at both orchards showed that $\mathrm{P}$ was in the adequate range $(0.09-0.26 \%)$ under the eucalyptus-wood-based-compostamended plots. Adequate leaf $\mathrm{P}$ levels were recorded from $5 \mathrm{tha}^{-1}$ and were in the high $(0.26-0.30 \%)$ range under $>5 \mathrm{tha}^{-1}$ eucalyptus-wood-based application rates. The observed increase in leaf $\mathrm{N}, \mathrm{P}, \mathrm{K}, \mathrm{Ca}$, and $\mathrm{Mg}$ levels with time could be due to the slow release of the nutrients from the cumulatively added eucalyptus-wood-based compost [22,24]. Magnesium deficiency in avocado orchards is so uncommon that this element can be placed in the same category with Ca and sulfur (S), which are considered critical only in exceptional cases. The results are in agreement with the study by [17,22] and [23], who reported the linear increase in leaf $\mathrm{N}$ and $\mathrm{K}$ contents with increasing organic matter levels in avocados.

\subsection{Leaf Micronutrients ( $\mathrm{Fe}, \mathrm{Mn}, \mathrm{Na}, \mathrm{Cu}$, and $\mathrm{Zn}$ )}

The results showed a significant $(p<0.05)$ increase of leaf $\mathrm{Fe}, \mathrm{Mn}$, and $\mathrm{Zn}$ levels with an increase in the applied rates of eucalyptus-wood-based compost except for $\mathrm{Na}$ and $\mathrm{Cu}$ from 2016 to 2018 at both orchards. All the micronutrients ( $\mathrm{Fe}, \mathrm{Mn}, \mathrm{Na}, \mathrm{Cu}$, and $\mathrm{Zn}$ ) leaf levels ranges indicated no deficiency supply (Table 1 ) of the nutrients at $>0 \mathrm{t} \mathrm{ha}^{-1}$ eucalyptuswood-based compost application rates at both orchards. Micronutrient deficiency or toxicity can occur under extreme $\mathrm{pH}$ levels. Although not measured in this study, the application of compost, at any rate, may not have negatively altered the soil $\mathrm{pH}$. The soil $\mathrm{pH}$ affects the solubility and availability of nutrients to the plants. Soil $\mathrm{pH}$ found avocado trees with a $\mathrm{pH}$ of 5.5-6.5, even with the application of the eucalyptus-wood-based compost, hence the observed micronutrient levels. The avocado trees become susceptible to Fe deficiency under soil conditions higher than $\mathrm{pH}$ 7.0, as calcium (Ca) will be the dominant cation in such soils, causing Fe to be fixed and become unavailable to the plant.

$\mathrm{Zn}$ and Fe are very critical microelements, as avocado is very susceptible to their deficiency. Symptoms of $\mathrm{Zn}$ deficiency are observed in acidic soils $(\mathrm{pH}<7)$ because it is easily leached at a low $\mathrm{pH}$, and in Ca-rich soils, $\mathrm{Zn}$ is fixed and becomes unavailable [13]. In most cases, $\mathrm{Zn}$ deficiency symptoms are similar to those of Fe in that once they appear, 
the symptoms cannot be reversed, and thus prevention is of prime importance. Deficiencies of other elements are not frequently observed in avocado orchards. The effect of compost application on the distribution of $\mathrm{Zn}$ depends on soil $\mathrm{pH}$ since the $\mathrm{pH}$ during this study was 7.0, which resulted in a slight increase of interchangeable $\mathrm{Zn}$. This could have resulted in organic complexation that mobilizes micronutrients [23].

\subsection{Avocado Fruit Yield and Size Distribution}

Avocado fruit yield and size distribution were significantly $(p<0.05)$ affected by the eucalyptus-wood-based compost application rates. Fruit yield was proportionally increasing with the quantities of compost applied each year. The highest yield was obtained at the $15 \mathrm{t} \mathrm{ha}^{-1}$ eucalyptus-wood-based application rates in 2018 . The cap for the eucalyptus-wood-based application rate was $>15 \mathrm{t} \mathrm{ha}^{-1}$ for the fruit yield; therefore, followup experiments of $>15 \mathrm{tha}^{-1}$ eucalyptus-wood-based application rates are necessary. In this study, the fruit yield was linearly related to the leaf nutrient content levels, where an increase in the nutrient leaf content corresponded to high fruit yields. The fruit size distribution was inversely related to the leaf nutrient levels; the largest proportion of fruits that follow the class 1 category were in the $15 \mathrm{t} \mathrm{ha}^{-1}$ eucalyptus-wood-based compost plots in 2018 at both Mooketsi and Politsi orchards, whereas the largest proportion of the avocado fruits in class 4 were under the $0 \mathrm{t} \mathrm{ha}^{-1}$ compost application rates in 2018. Our results agree with [10], who also reported an in avocado yield and fruit size with an increase in leaf nutrient content under different composted pine park quantities. Similar results were noted by [8], who showed strong evidence that soil $\mathrm{N}$ application rates of organic compost were an important factor influencing 'Hass' avocado yield. However, other $\mathrm{N}$ fertilizer application rate experiments results have shown that 'Hass' avocado yield and fruit size were not related to leaf $\mathrm{N}$ concentration [1].

\section{Conclusions}

Eucalyptus-wood-based compost had a cumulative significant $(p<0.05)$ effect on macro-and micronutrient leaf concentrations and fruit yield in all 3 years of the study. Leaf $\mathrm{N}, \mathrm{P}, \mathrm{K}, \mathrm{Ca}, \mathrm{Mg}, \mathrm{Fe}, \mathrm{Zn}, \mathrm{Mn}$, and $\mathrm{Cu}$ levels increased proportionally to the applied quantities of the eucalyptus-wood-based compost and were all within the ranges considered optimal for avocado in South Africa (Table 1) from 2016 to 2018 under compost-amended plots. Leaf $\mathrm{Na}$ levels were below $(0.19 \%)$ the toxicity level for avocado production in all the eucalyptus-wood-based compost application rates. In this study, the macro- and micronutrient leaf contents were adequately supplied with $5 \mathrm{t} \mathrm{ha}^{-1}$ eucalyptus-wood-based compost; however, a high (15 $\left.\mathrm{t} \mathrm{ha}^{-1}\right)$ compost application rate was required for high fruit yield and large fruit sizes. It is recommended to apply eucalyptus-wood-based compost in a quantity of at least $5 \mathrm{tha}^{-1}$ to achieve adequate leaf nutrient levels, but high $\left(>10 \mathrm{t} \mathrm{ha}^{-1}\right)$ applications were ideal for high (19.6 $\mathrm{t} \mathrm{ha}^{-1}$ ) yield and large fruit size (class 1) at both the Mooketsi and Politsi orchards. In addition, compost treatment could result in some mulching performance and improvement of other soil properties; however, our study did not look at the soil moisture dynamics and soil properties-we therefore recommend further research on this aspect.

Author Contributions: Conceptualization, A.M. and M.P.M.; methodology, A.M.; software, C.P.; validation, A.M., M.P.M. and M.Z.; formal analysis, C.P.; investigation, M.P.M.; resources, M.Z.; data curation, C.P.; writing-original draft preparation, M.P.M.; writing-review and editing, C.P. and A.M.; visualization, M.P.M.; supervision, A.M. and M.Z.; project administration, M.P.M.; funding acquisition, A.M. All authors have read and agreed to the published version of the manuscript.

Funding: This research was funded by the National Research Fund (NRF) and ZZ2 Bertie van Zyl (Pty) Ltd., South Africa.

Acknowledgments: The authors are grateful to the Zimbabwe Open University for providing updated statistical software during data analysis. 
Conflicts of Interest: The authors declare that they have no known competing financial interests or personal relationships that could have appeared to influence the work reported in this paper.

\section{References}

1. Lovatt, C.J. Hass avocado nutrition research in California. Cali Avocado Soc. 2014, 96, 74-105.

2. Gwenzi, W.; Muzuva, M.; Mapanda, F.; Tauro, T.P. Comparative short-term effects of sewage sludge and its biochar on soil properties, maize growth and uptake of nutrients on a tropical clay soil in Zimbabwe. J. Integ. Agric. 2016, 15, 1395-1406. [CrossRef]

3. Griffiths, B.S.; Ball, B.C.; Daniell, T.J.; Neilson, R.; Wheatley, R.E.; Osler, G.; Bohanec, M. Integrating soil quality changes to arable agricultural systems following organic matter addition, or adoption of a ley-arable rotation. Appl. Soil Ecol. 2010, 46, 43-53. [CrossRef]

4. Nguyen, T.H.; Shindo, H. Effects of different levels of compost application on amounts and distribution of organic nitrogen forms in soil particle size fractions subjected mainly to double cropping. Agric. Sci. 2011, 2, 213-219. [CrossRef]

5. Wolstenholme, B.N.; Moore-Gordon, C.; Ansermino, S.D. Some pros and cons of mulching avocado orchards. SA Avocado Growers' Assoc. 1996, 19, 87-91.

6. El-Shamma, M.S.; Mona, E.M.H.; Maksoud, M.A.; Fekria, H.K.; Mansour, A.E.M. Effect of some bio-stimulants on nutritional status, yield and fruit quality of avocados. Mid. East J. Agric. Res. 2017, 6, 692-699.

7. Angelova, V.R.; Akova, V.I.; Artinova, N.S.; Ivanov, K.I. The effect of organic amendments on soil chemical characteristics. Bulg. J. Agric. Sci. 2013, 19, 958-971.

8. Fujihiro, A.; Nkkiko, K.; Chio, K. Effects of compost and organic green manure on soil fertility and nutrient uptake in wheat-rice cropping system. Int. J. Man. Fert. 2013, 2, 407-412.

9. Wolsterholme, B.N.; Moore-Gordon, C.; Cowan, A.K. Orchard mulching effects on avocado fruiting. In Proceedings of the Conference '97: Searching for Quality. Joint Meeting of the Australian Avocado Grower's Federation and New Zealand Avocado Growers Association, Rotorua, New Zealand, 23-25 September 1997; pp. 119-130.

10. Moore-Gordon, C.; Cowan, A.K.; Wostenholme, B. Mulching of avocado orchards to increase Hass yield and fruit size and boost financial rewards a three season summary of research findings. SA Avocado Growers' Assoc. 1997, 20, 46-49.

11. Bonilla, N.; Vida, C.; Martínez-Alonso, M.; Landa, B.B.; Gaju, N.; Cazorla, F.M.; de Vicente, A. Organic amendments to avocado crops induce suppressiveness and influence the composition and activity of soil microbial communities. Appl. Environ. Microbiol. 2015, 81, 3405-3418. [CrossRef] [PubMed]

12. Duong, T.T.T.; Verma, S.; Penfold, C.; Marschner, P. Nutrient release from composts into surrounding soil. Geoder 2013, 195-196, 42-47. [CrossRef]

13. Sahoo, R.; Bhardwaj, D.; Tuteja, N. Biofertilizers: A sustainable eco-friendly agricultural approach to crop improvement. In Plant Acclimation to Environmental Stress; Tuteja, N., Singh Gill, S., Eds.; Springer: New York, NY, USA, 2013; pp. $403-432$.

14. Krasniqi, A.L.; Blanke, M.M.; Kunz, A.; Damerow, L.; Lakso, A.N.; Meland, M. Alternate bearing in fruit tree crops: Past, present and future. Acta Hortic 2017, 1177, 241-248. [CrossRef]

15. Scaffer, B.; Wolstenholme, N.B.; Whiley, A. Avocado Botany, Production and Uses, 2nd ed.; CABI Publishing: New York, NY, USA, 2013; pp. 15-19.

16. Hartigh, W. ZZ2's, 10,000 Tons of Avocados Using Nature-Friendly Methods; Farmer's Weekly Magazine: Pretoria, South Africa, 2016; pp. 34-42.

17. Oldfield, E.E.; Wood, S.A.; Bradford, M.A. Direct effects of soil organic matter on productivity mirror those observed with organic amendments. J. Plant Soil 2018, 423, 363-373. [CrossRef]

18. Mohale, M.P.; Manyevere, A.; Dube, E.; Zerizghy, M. Short-term Effect of Eucalyptus Wood-based Compost on Biological Fertility of Soils under Avocado Plantations. Comm. Soil Sci. Plant Anal. 2021, 52, 1574-1589. [CrossRef]

19. Mohamed, A.A.; Castagna, A.; Ranieri, A.; di Toppi, L.S. Cadmium tolerance in Brassica juncea roots and shoots is affected by antioxidant status and phytochelatin biosynthesis. Plant Phys. Biochem. 2012, 57, 15-22. [CrossRef] [PubMed]

20. Estefan, G.; Sommer, R.; Ryan, J. Methods of Soil, Plant, and Water Analysis: A manual for the West Asia and North Africa Region, 3rd ed.; ICARDA: Beirut, Lebanon, 2013; p. 244.

21. Whiley, A.W.; Smith, I.E.; Wolstenholme, B.N.; Saranah, J.B. Boron nutrition of avocados. SA Avocado Growers' Assoc. 1996, $20,1-7$.

22. Barbosa, M.A.; Ferreira, N.M.; Bertino, A.M.P.; Mesquita, E.F.; Chaves, L.H.G.; Cavalcante, L.F.; Rigobelo, E.C. Effect of organic matter, irrigation and soil mulching on the nutritional status and productivity of okra (Abelmoschus esculentus L.) in the semiarid region of Brazil. Afric. J. Biotech. 2016, 15, 2720-2728.

23. Parwada, C.; Mandumbu, R.; Tibugari, H.D.; Badze, D.; Mhungu, S. Effect of soil fertility amendment, planting density and growing season on Chenopodium quinoa Willd (Quinoa) in Zimbabwe. Cogent Food Agric. 2020, 6, 1-16. [CrossRef]

24. Villena, R.; Castellanos, M.T.; Cartagena, M.C.; Ribas, F.; Arce, A.; Cabello, M.J.; Requejo, M.I. Winery distillery waste compost effect on the performance of melon crop. Sci. Agric. 2018, 75, 494-503. [CrossRef] 